\title{
Analytical platform to provide competitiveness of ore-mining machinery manufacturing
}

\author{
Olena Parshyna ${ }^{1 * \otimes(0)}$, Yurii Parshyn ${ }^{1 \otimes(1)}$ \\ ${ }^{1}$ Dnipropetrovsk State University of Internal Affairs, Dnipro, 49005, Ukraine \\ *Corresponding author: e-mail parschina@ukr.net, tel. +380504800836
}

\begin{abstract}
Purpose is to develop analytical platform providing competitiveness of ore-mining machinery manufacturing.

Methods. The analytical platform combines five modular blocks. It involves determination of an area of optimum process conditions for each tool - part pair. Studies of processibillity by means of cutting were carried out in a production environment of NKMZ CJSC using parts of a spindle type made of 38XH3MFA steel. For the experiments, cutters, made of different tool materials were prepared; they were turned by means of a diamond disc with the provision of definite geometric parameters. The parts were cut using a chasing lathe1 A680 with no cooling. Flank wear was assumed as a criterion of cutter bluntness.

Findings. Correlations of operating procedures of ore-mining machinery part processing have been identified. Among other things, regularities of wear bit have been defined taking into consideration the influence on accuracy and quality of the surface under processing depending upon the manufacturing system stiffness as well as upon the conditions of fixing of the parts during the tooling. Methods have been developed to define safety margin of the manufacturing system making it possible to show reserves for the improvement of competitiveness of ore-mining machinery production in view of the specified accuracy and processing quality limits. Mathematical models have been developed which practical use helps determine areas of optimum modes of ore-mining equipment part machining; and represent comparative characteristic of procedures taking into consideration processing accuracy and wear impact on the dimensional stability of a cutter.

Originality. It has been substantiated scientifically that the area of optimum modes is identified in terms of the system totality of the proposed criteria inclusive of the specified indices of quality, accuracy, and efficiency of procedures to process parts of ore-mining machines.

Practical implications. The identified regularities are analytical framework to make decisions providing manufacturing competitiveness owing to optimization of procedure as well as to the improvement of accuracy, processing quality, and functional reliability of the parts of ore-mining machines.
\end{abstract}

Keywords: cutting process modeling, parts of ore-mining machines, quality indices, processing accuracy

\section{Introduction}

Creation of conditions for the efficient use of mineral resource potential in terms of the sustainable development of extractive industry is the critical mission of energy security. Since 2015, positive dynamics of the extraction share increase in gross domestic product (GDP) of Ukraine has been observed. Namely, if extraction share in GDP was 5\% in 2015 and $6.1 \%$ in 2017 , it achieved $6.5 \%$ in 2019 [1]. Average growth rate of the extractive industry was $1.8 \%$ in 2015-2019. The fact supports the idea of positive development tendency of the dominant sector of the national economy in terms of energy security provision, and Ukrainian budget filling.

Analysis of the extractive sector in the world market also makes it possible to suggest development processes. Analysts of DTEK Company expect increase in the global dynamics of coal consumption in oil equivalent. Among other things, if coal consumption is estimated as 3800 mln tons in 2020, its increase is predicted up to $4500 \mathrm{mln}$ tons in 2040 [2].

Taking into consideration the tendencies as well as complex conditions of equipment operation during mineral extraction, it is necessary to single out the demands placed on the ore-mining facilities:

- provision of maximum possible engineering efficiency while achieving high values of the key parameters characterizing quality level and competitiveness degree of ore-mining machines under the complicated operation conditions;

- provision of a high level of functional reliability of oremining machines (among other things, no less than $80 \%$ service life before their thorough repairs);

- provision of relatively low specific power consumption.

Mining industry applies tunneling machines to drive development mine workings in mines, and to build various underground structures. Their use helps combine in time the 
basic technological operations; obtain 2-3 times raise in labour productivity; and provide labour safety of miners, operating in development mine workings to compare with the technology of drill and blast tunneling method.

Currently, tunneling machines of such brands as CARTER, CATERPILLAR, SANDVIK, WIRTH, NKMZ, YaMZ etc. are the most popular ones. Tunneling machines of P110 type, produced by Novokramatorsk machine-building plant, are characterized by high performance; their service life to the first thorough repairs is 120000 to 150000 cubic meters of the broken rock mass depending upon the machine type; and relatively low maintenance costs per one mining meter.

Ore-mining facilities operate under complex conditions where intensive wear of working surfaces of parts of its major assemblies and mechanisms take place. The abovementioned results in the decreased engineering reliability and economic efficiency of practical use of the equipment as a consequence.

A list of the principal target tasks of the Energy Strategy of Ukraine through 2035 (Ordinance of the Cabinet of Ministers of Ukraine of $18^{\text {th }}$ August 2017 \#605-p) [3] mentioned the necessity to provide the country demand for fuel and energy resources while using safe and economically expedient methods of mineral mining. In this context, the need originates to apply wear-resistant steel grades for ore-mining machinery manufacturing. That will help improve functional reliability of the facilities owing to maximum use of service life of the essential parts and mechanisms.

However, even if the increased strength characteristics of the wear-resistant steel grades are taken into consideration, problems of control of quality and accuracy of tooling remain actual involving further research since they are the foundation of ore-mining machinery competitiveness. Specific attention should be paid to tooling procedures of the parts of a rotation body type. The matter is that the group of parts becomes basic one while evaluating service life until the first thorough repairs. Moreover, it exercises dominant influence on the competitive strength of the enterprise, and provides high functional reliability of the ore-mining machinery.

The improvement of competitiveness of ore-mining machinery manufacturing under the conditions of large machine-building enterprise and under the current economic conditions is possible if only high quality of operational procedures is available. Development of modern equipment for extractive industry is connected with the elaboration of the advanced technologies and their improvement resulting from the optimization of tooling of ore-mining equipment parts.

Optimization of tooling of parts, to which high demands are made as for their physical and mechanical characteristics as well as indices of accuracy and quality of the machined surfaces, will help create the foundations to provide competitiveness of the ore-mining equipment manufacturing. Machining of such parts demonstrates rather high intensity of cutting tool wear; the procedures are characterized by instability of machining quality indices depending upon specific features of wear-resistant steel and upon the procedure stiffness.

It has been identified that machining conditions (especially cutting modes) exercise a significant influence on the manufacturing system state. Changes in advance and cutting depth effect cutting force intensity. The effect is especially important when wear-resistant steel is machined since it results in high temperature initiation within the cutting areas.
Thus, intensive wear decrease sharply the cutting power deteriorating significantly the indices of finishing quality.

Modern scientific sources place high emphasis on the problems of wear-resistant steel grades. In particular, paper [4] mentions that tooling of difficult-to-machine materials is a complex problem due to their low machinability resulting in loss of efficiency and high manufacturing cost. In paper [5], Parida, A., Rao, P., and Ghosh, S. single out that low thermal conductivity and high deformational rate cause problems in the process of wear-resistant steel tooling which factors into the intensive cutting and tool degradation. The carried out research [6] has helped determine that the cutting edge wear increases during machining and results in the cutting force intensity, surface roughness, and the product quality degradation. Paper [4] states that stock removal rates are limited due to a high rate of the tool wear.

Paper [7] considers effect of the material, being machined, on the cutting power of tool hard alloys. It has been defined that owing to physical and mechanical characteristics, and chemical composition, a material, being machined, determines optimum cutting modes as well as a form and nature of the tool wear intensity dependence upon the cutting temperature.

Paper [8] analyzes influence of cutting rate and advance rate on a surface roughness, cutting force, and tool wear. The results have shown that advance rate is a more important parameter influencing both surface roughness and cutting force.

Improvement of research efficiency needs the use of modeling methods making it possible to carry out simulation experiments; identify the available dependences; and determine optimum parameters. In particular, authors of paper [5] performed modeling with the use of DEFORM software to analyze cutting intensity, tool temperature, and facing morphology in terms of different cutting rates and advance rates.

Authors of [9] represent the developed plan of calculation experiment used to analyze results and define conditions for efficient 2D modeling of cutting processes. Paper [10] analyzed results of calculation studies of dynamics of force variation in terms of orthogonal cutting.

Since cutting temperatures exercise a significant influence on a service life of a tool, authors of paper [11] have developed a model to analyze heat transfer and temperature distribution in terms of lathe turning of products made of the hardened steel.

The developed models of predictable time, represented to analyze a cutting tool wear, cutting force, and surface roughness from the viewpoint of tooling conditions, demonstrate that the studied parameters are sensitive to time where time factor should be considered not only for wear but also for the consumed power and the product quality [6]. Optimization results have been obtained and represented to increase service life of a tool; to minimize production cost; or to minimize production time [6].

The research results have shown that the increased competitiveness of ore-mining facilities is intimately connected with the optimization of machining processes on the basis of the indentified regularities of a cutting ability. Evaluation of the phenomena is always of relative nature depending upon specific working conditions and numerous processing factors. In particular, rough machining stage should involve a cutter wear as the key machinability index. Final machining, requiring provision of the specified processing accuracy as well as the required quality of the machined surface, should 
identify cutting modes taking into consideration a number of factors acting in the process of nonstationary cutting process. In particular, it is necessary to involve the features of phenomena of machinability with the help of different tools in view of dynamic stiffness of the manufacturing system.

The problems to identify optimum cutting modes taking into consideration the specified quality indices and processing accuracy, being the key competitiveness rates of oremining machinery manufacturing, needs further research. To solve the set of problems connected with the competitiveness provision, it is required to have new scientific approaches intended to identify regularities in the operating procedures with the use of analytical methods and modern software.

\section{Methods}

Analytical platform to provide competitiveness of oremining machinery manufacturing has been developed by the authors. Figure 1 demonstrates structural scheme of the platform. The latter involves five modular blocks.

Modular block I. Industrial experiment
Mathematical models of cutting duration influence
on wear of tools

Figure 1. Structural scheme of the analytical platform to provide competitiveness of ore-mining machinery manufacturing

Modular block one foresees industrial experiment which key mission is to analyze processing properties of the parts made of 38XH3MFA steel with high physical and mechanical characteristics. Modular block two involves simulation of cutting processes and development of a complex of mathematical models. Among them there are mathematical models to determine the influence of cutting duration on wear of tools; mathematical models to determine cutting velocity influence of a surface roughness; and mathematical models to determine influence of cutting tool supply on the surface roughness. Modular block three is a block to develop computational models for simulation of cutting processes and their analysis. Its major aim is to identify tolerable range of changes in cutting modes taking into consideration the specified accuracy and stiffness indices of the manufacturing system. Modular block four is intended to determine conditions of the manufacturing system optimum functioning. Modular block five is to form solution for competitive manufacturing of ore-mining machines.

Optimization of the operating procedure of cutting of the ore-mining facilities parts is based upon a study of machinability phenomena relation. Among other things, it concerns regularities of cutter wear as well as its influence of accuracy and quality of machinable surface taking into consideration the manufacturing system stiffness and conditions of the workpiece positioning during mechanical processing. Optimum area of cutting modes is determined in terms of a set of criteria inclusive of the specified indices of quality, processing accuracy, and the technology efficiency. Criteria of the machining accuracy and quality generate a system of limitations as for the cutting and supply. The analytical platform involves determination of optimum cutting mode area for each tool - part pair.

Methods to define accuracy margin of a manufacturing system have been developed. That makes it possible to define the potential to improve processing efficiency within the area of tolerable cutting modes in terms of meeting the specified limitations as for the machining accuracy and quality. To identify the area of optimum modes, to calculate comparative machinability characteristics and processing accuracy, and to analyze wear influence on the dimensional tool durability, mathematical models, combined in modeling moduli, have been developed. The complex of mathematical models makes it possible to simulate processing modes. In this context, results of machinability studies (in particular, wear variables in terms of flank wear and processing roughness obtained during the industrial experiments) are the input data.

Cutability was studied under production conditions of NKMZ CJSC. Parts of spindle types, made of 38XH3MFA steel were used. Cutters, produced from different tool materials, were prepared for the experiments. Among them are: single-carbide tungsten alloy BK6OM, and two-carbide (titanium-tungsten) hard alloys T5K10 and T15K6. Talking into account production experience, the cutters were edged using a diamond disk. Following geometry was met: $\gamma=10^{\circ}$, $\varphi=45^{\circ}, \varphi_{1}=15^{\circ}, \lambda=0$.

Parts with $300 \mathrm{~mm}$ diameter were cut using chasing lathe 1 A680 with no cooling. Cutting depth was $1.5 \mathrm{~mm}$; supply was $0.3 \mathrm{~mm} / \mathrm{rev}$. Flank wear being $h_{z}=0.7 \mathrm{~mm}$ was assumed as a criterion of a cutter blunting.

\section{Results and discussion}

The research has demonstrated regularities of a cutter wear intensity depending upon the tool instrument grade. In particular, it has been identified that cobalt content increase in a tool material results in the intensity of cutter wear. BK6OM tools are characterized by greater flank wear intensity in terms of 38XH3MFA steel processing. Figure 2 explains the research results, i.e. cutter wear dependence upon cutting duration as well as modeling results of the cutting processes. Mathematical models, being dependences of the cutter wear upon cutting duration while processing parts made of 38XH3MFA steel, were obtained using a method of least squares [12]. 


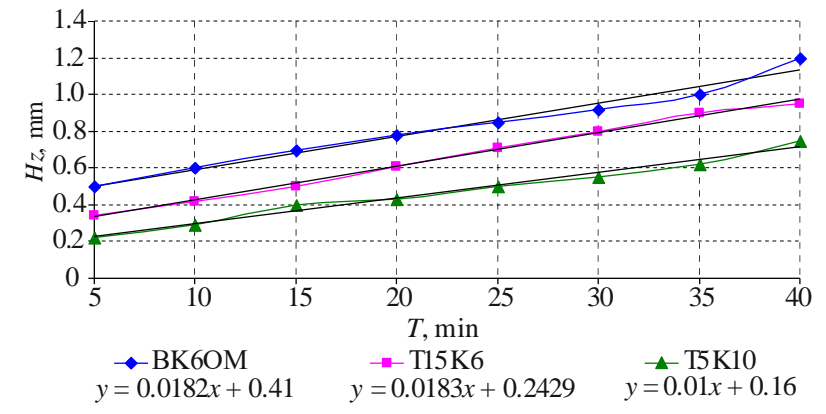

Figure 2. Influence of cutting duration on the cutter wear while processing parts made of $38 \mathrm{XH3MFA}$ steel

Parameters of the mathematical models (Table 1) help represent quantitative evaluation of the cutter tool wear upon cutting duration. In particular, the intensity of BK6OM cutter wear is almost twice higher than the intensity of T5K10 tools. Evaluation of the modeling accuracy is indicative of the sufficient adequacy of the dependences.

Table 1. Modeling of $\mathrm{Hz}$ cutter wear relation upon cutting duration $T$ while processing the parts made of $38 \mathrm{XH} 3 \mathrm{MFA}$ steel

\begin{tabular}{|c|c|c|c|}
\hline \multirow[b]{2}{*}{$\begin{array}{l}\text { Cutter } \\
\text { grade }\end{array}$} & \multirow[b]{2}{*}{$\begin{array}{c}\text { Mathematical } \\
\text { model }\end{array}$} & \multicolumn{2}{|c|}{ Modeling accuracy evaluation } \\
\hline & & $\begin{array}{c}\text { Sum of squared } \\
\text { deviations }\end{array}$ & $\begin{array}{c}\text { Determination } \\
\text { coefficient }\end{array}$ \\
\hline BK6OM & $H z=0.02 T+0.41$ & 0.025 & 0.98 \\
\hline T15K6 & $H z=0.02 T+0.24$ & 0.015 & 0.99 \\
\hline $\mathrm{T} 5 \mathrm{~K} 10$ & $H z=0.01 T+0.16$ & 0.078 & 0.98 \\
\hline
\end{tabular}

The studies of cutability on roughness upon cutting velocity in terms of constant supply $S=0.25 \mathrm{~mm} / \mathrm{rev}$ are shown in Figure 3. The roughness was measured with the help of profilograph-profilometer TAYLOR-HOBSON / Surtronik-3.

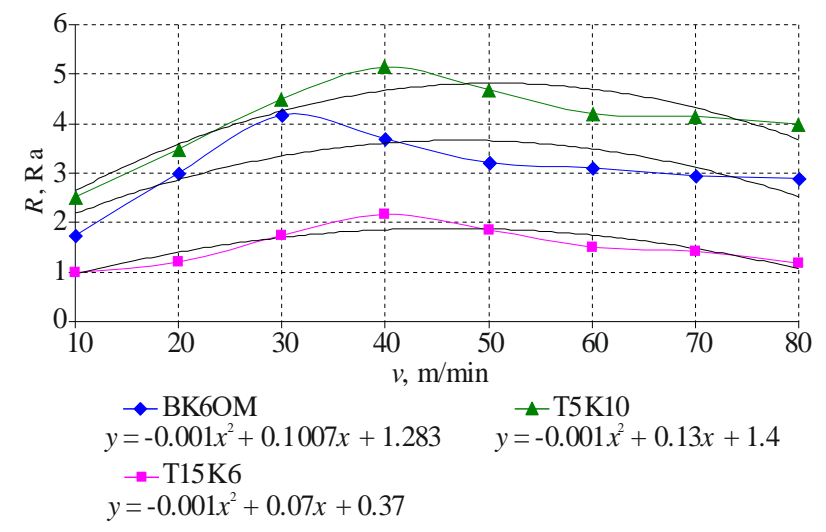

Figure 3. Cutting velocity influence on a surface roughness

Analysis of the results has demonstrated that processing at low cutting velocity is characterized by low roughness. If cutting velocity increases up to $30-40 \mathrm{~m} / \mathrm{min}$, roughness growth is observed. The growth depends upon the cutter outgrowth. If cutting velocity is $50 \mathrm{~m} / \mathrm{min}$ and more then height of irregularities decreases. It should be noted that the processed surface quality depends upon the selected toolpart pair. It has been defined that cobalt content increase in a tool material factors into the increased roughness of the processed surface. Processing of parts, made of 38XH3MFA steel using T15K6 tools, are characterized by less roughness degree to compare with T5K10 cutters.

Analysis of the research has helped select the most optimum grade of an instrumental tool relying upon the criterion of achievement of the required roughness of the processed surface. However, cutting velocity should be limited by tool wear intensity since the value exercises a significant influence on the processing accuracy and on the operating procedure prime cost. It is important to note that cutting supply is dominant both for the cutter wear intensity and for the processed surface roughness.

Mathematical models, shown in Table 2, have been developed for quantitative evaluation of cutting velocity influence on a surface roughness while processing parts made of 38XH3MFA steel. A method of least squares was applied. Parameters of the mathematical models make it possible to obtain quantitative evaluation of cutting velocity influence on a surface roughness. Among other things, cutting of parts made of 38XH3MFA steel using T15K6 cutters are characterized by higher index of processing quality stability.

Table 2. Modeling of cutting velocity influence on the surface roughness while processing the parts made of 38XH3MFA steel

\begin{tabular}{cccc}
\hline \multirow{2}{*}{$\begin{array}{c}\text { Cutting } \\
\text { tool } \\
\text { grade }\end{array}$} & Mathematical model & \multicolumn{2}{c}{$\begin{array}{c}\text { Evaluation of the } \\
\text { modeling accuracy }\end{array}$} \\
\cline { 3 - 4 } & & $\begin{array}{c}\text { Sum of } \\
\text { squared } \\
\text { deviations }\end{array}$ & $\begin{array}{c}\text { Deter- } \\
\text { mination } \\
\text { coefficient }\end{array}$ \\
\hline T5K10 & $R=-0.001 V^{2}+0.13 V+1.4$ & 6.60 & 0.8 \\
BK6OM & $R=-0.001 V^{2}+0.1007 V+1.283$ & 1.80 & 0.6 \\
T15K6 & $R=-0.001 V^{2}+0.07 V+0.37$ & 4.64 & 0.8 \\
\hline
\end{tabular}

Figure 4 represents analysis of the processed surface roughness depending upon the supply in terms of $V=50 \mathrm{~mm} / \mathrm{min}$ cutting velocity. In the context of final machining, supply limitations as for the processing roughness should be introduced. In this connection, a dependence of cutting supply and cutting velocity upon a manufacturing system stiffness and conditions of a raw part positioning on a lathe has been studied taking into consideration the specified processing accuracy.

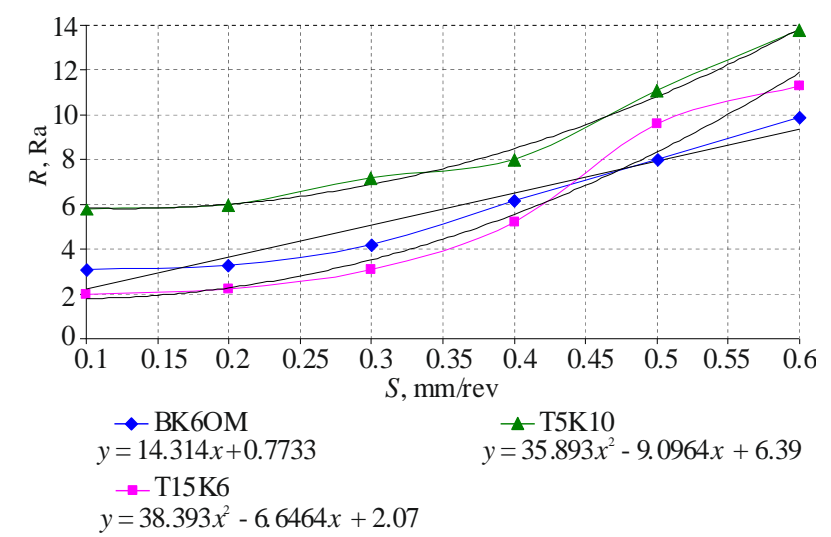

Figure 4. Cutting supply influence on the surface roughness

Mathematical models have been developed for quantitative evaluation of supply influence on a surface roughness while processing 38XH3MFA steel (Table 3).

Parameters of the mathematical models make it possible to evaluate supply influence on a surface roughness. In particular, it has been defined that the processes of cutting the part from 38XH3MFA using T15K6 and BK6OM cutters provide better processing quality in terms of the surface roughness. 
Table 3. Modeling of supply influence on the surface roughness while processing the parts made of $38 \mathrm{XH} \mathrm{MF} A$ steel

\begin{tabular}{cccc}
\hline \multirow{2}{*}{$\begin{array}{c}\text { Cutting } \\
\text { tool } \\
\text { grade }\end{array}$} & Mathematical model & \multicolumn{2}{c}{$\begin{array}{c}\text { Evaluation of the } \\
\text { modeling accuracy }\end{array}$} \\
\cline { 3 - 4 } & & $\begin{array}{c}\text { Sum of } \\
\text { squared } \\
\text { deviations }\end{array}$ & $\begin{array}{c}\text { Deter- } \\
\text { mination } \\
\text { coefficient }\end{array}$ \\
\hline T5K10 & $R=35.89 S^{2}-9.096 S+6.39$ & 0.43 & 0.99 \\
BK6OM & $R=14.314 S+0.77$ & 2.05 & 0.95 \\
T15K6 & $R=38.39 S^{2}-6.65 S+2.07$ & 2.30 & 0.97 \\
\hline
\end{tabular}

The industrial experiments have helped identify that the parts, manufactured during one and the same operating procedure, are characterized by significant dissipation of quality indices. Taking into consideration the fact that accuracy is one of the most important characteristics, influencing functional reliability of ore-mining machinery, the accuracy index should be considered as one of the basic characteristics of the final machining. Thus, it is necessary to analyze the reasons of processing error origination; and develop methods to control accuracy from the viewpoint of cutability of the processed parts.

Numerous observations have shown that knowledge of the total processing error involving cutting process dynamics while using the selected equipment in terms of proper setting is quite important for the final machining stage. The abovementioned will help solve correctly the problem of optimization of cutting modes based upon machining features, the specified accuracy, and stiffness of a manufacturing system.

Despite the fact that cutting of the analyzed parts at the final stage is also characterized by rather intensive wear of cutters, optimization of cutting modes in this context will be of relative nature depending upon tolerable stability of cutting tools. Moreover, it will prevent from determination of cutting modes in view of the required accuracy.

Hence, there is a necessity to develop such a system of indices considering both cutability features and dynamic phenomena taking place within a manufacturing system and influencing processing accuracy. Thus, it is required to analyze the reasons of processing error origination; evolve methods to control the total processing error taking into consideration cutability of parts; and develop software to forecast possible tool error before the industrial experiment start.

Solving the problem of the increased cutting accuracy needs a system approach to the study of elastic deformations of the parts being processed. The abovementioned should involve consideration of dynamic action of cutting forces; manufacturing system stiffness; and cutter wear influence of the dimensional accuracy of the processed parts in addition to the consideration of permissible deflection of one part as it is indicated in numerous regulatory data and reference books for technologists.

Analyze elastic deformation originated during lathe machining of centre fixed cylindrical parts (in this context, the deformations resulting from the influence by shackle and driver are not involved since they are minor).

Relying upon the permissible deflections and elastic displacements of a part blank on lathe supports $f_{d o p}$, it is possible to identify adequate cutting forces as well as cutting modes corresponding to them.

Use [13], [14] equation for the purpose:

$$
F_{\text {din }}>f_{\text {dop }} \text {, }
$$

where:

$f_{\text {dop }}$ - tolerable elastic displacement;

$f_{\text {din }}$ - dynamic elastic displacement, $f_{\text {din }}=f_{m} \cdot \mu$;

$f_{m}$ - static displacement;

$\mu$-dynamic coefficient.

A part deflection in terms of static load application is known [14]:

$f_{c m}=\frac{P_{u з M} \cdot l^{3}}{48 \cdot E \cdot I} \cdot \mu$

where:

$l$ - length of the part blank being processed;

$E$ - elasticity modulus of the processed material;

$I=\frac{\pi \cdot d^{4}}{64}-$ inertia of the part cross section;

$d$-diameter of the part being processed.

While inserting formula (2) into (1) obtain the basic limitation:

$f_{\text {din }}=\frac{P_{i z g} \cdot l^{3}}{48 \cdot E \cdot I} \cdot \mu \leq f_{m}$.

After the transformation of expression (3), obtain a value of the tolerable cutting force $P z$ which value corresponds to the tolerable elastic displacement $f_{\text {dop }}$ :

$$
P z_{d o p}=\frac{3 \cdot E \cdot I \cdot \pi d^{4} \cdot f_{d o p}}{4 \cdot \sqrt{1.25} \cdot \mu \cdot l^{3}} .
$$

Taking into consideration a cutter state (in particular, for sharp cutters), tolerable cutting force is [14]:

$$
P z_{d o p}=\frac{1.9 \cdot E \cdot f_{d o p} \cdot d}{c^{3} \cdot \mu},
$$

and tolerable cutting force for blunt cutters is:

$$
P z_{d o p}=\frac{1.5 \cdot E \cdot f_{d o p} \cdot d}{c^{3} \cdot \mu} .
$$

Complete tolerable deformation, characterizing the required machining accuracy, consists of the lathe deformation $f_{c}$ and the part deformation $f_{d}[14]: f_{d o p}=f_{c}+f_{d}$.

$f_{d}$ value is determined using formula (2). Lathe deformation towards the force effect is [14]:

$$
f_{c}=\frac{P_{i z g}}{j_{s}}+\frac{P_{i z g}}{4}\left(\frac{1}{j_{p}}+\frac{1}{j_{z}}\right),
$$

where:

$j_{s}$ - caliper stiffness;

$j_{p}$ - head stock stiffness;

$j_{z}-$ dead head stiffness.

Hence, taking into consideration the lathe stiffness, the tolerable cutting force is [14]:

$$
P z_{d o p}=\frac{k \cdot E \cdot d \cdot f_{d o p}}{c^{3} \mu+\left[\frac{1}{j_{s}}+\frac{1}{4}\left(\frac{1}{j_{p}}+\frac{1}{j_{z}}\right)\right] \cdot 2.1 \cdot E \cdot d},
$$

where: 
$k=1.9$ for $P y=0.5 \cdot P z \quad$ (sharp cutters); $k=1.5$ for $P y=P z$ (blunt cutters);

$c$ - manufacturing system stiffness.

As it is known [13], the manufacturing system stiffness is identified with the help of $\frac{d}{l}=c$ ratio. If stiffness is ideal $\left(j_{c}=\infty\right)$, then $P z$ formula acquires its original form.

The formulas are used to develop algorithm, research methods, and mathematical model to analyze processing errors, cutting forces, and optimization of machining modes in terms of the specified limitations on the accuracy indices. Cutting velocity ranges of machining of parts, made of 38XH3MFA steel, are applied as the initial data (statistics by the industrial experiment). The modeling identifies tolerable cutting force as well as cutting modes providing the specified processing accuracy.

Further research is carried out for the conditions of a part fixation in a holder (another end of the part rests on the back centre). Tolerable part deflection is determined using the formula $f_{\text {din }}=f_{m} \cdot \mu \leq f_{\text {dop }}$.

A value of the maximum static deflection for the case of beam supporting is known [14]:

$$
f_{\max }=0.0098 \cdot \frac{P_{i z g} \cdot l^{3}}{E \cdot I} .
$$

If deflecting cutting force for sharp cutters is [14] $P_{i z g}=\sqrt{1.25} \cdot P z$ then:

$f_{\text {din }}=\frac{\sqrt{1.25} \cdot P z \cdot \mu \cdot l^{3}}{102 \cdot E \cdot I} \leq f_{d o p}$

Use of formula (8) helps analyze the principal component of the cutting force from the specified value of tolerable deflection $P z=\frac{102 \cdot E \cdot I \cdot f_{d o p}}{\sqrt{102} \cdot \mu \cdot l^{3}}$.

While modeling, apply formulas from paper [14] taking into consideration conditions of cutting tools, namely:

$P z=\frac{4.4 \cdot E \cdot d \cdot f_{d o p}}{c^{3} \cdot \mu}-$ for sharp cutters;

$P z=\frac{3.5 \cdot E \cdot d \cdot f_{d o p}}{c^{3} \cdot \mu}-$ for blunt cutters.

In terms of such part fixation, lather deformation $f_{c}$ is identified using formula (7).

Formula [14] is applied to analyze $P z$ force taking into consideration the manufacturing system stiffness in terms of the conditions of the part fixation and tolerable deflection:

$$
P z=\frac{k \cdot E \cdot d \cdot f_{d o p}}{c^{3} \mu+\left[\frac{1}{j_{s}}+\frac{1}{4}\left(\frac{1}{j_{p}}+\frac{1}{j_{z}}\right) \cdot 4.8 \cdot E \cdot d\right]},
$$

where:

$k=4.4$ if $P y=0.5 \cdot P z$ (sharp cutters);

$k=3.5$ if $P y=P z$ (blunt cutters).

Processing errors and cutting forces are analyzed with the help of analytical models with the use of multifunctional integrated application package MathCAD. Information, concerning the processing modes, has been formulated relying upon the results of industrial experiments of cutability of oremining machinery pats made of 38XH3MFA steel.

In this context, theoretical cutting force is calculated using formula [15]:

$P z=C p \cdot V^{-0.15} \cdot S^{0.75} \cdot t^{0.95}$,

where:

$C p$-constant coefficient taken from the reference materials [15];

$V, S, t$ - velocity (m/min), supply ( $\mathrm{mm} / \mathrm{rev})$, and cutting depth (mm).

In the context of the modeling, cutting force with variational values of cutting depth or supply is calculated using [15]:

- turning with more than $0.07 \mathrm{~mm} / \mathrm{rev}$ supplies using cutters where blades are made of T15K6 and T5K10 alloys:

$V=\frac{C_{v}}{T^{0.35} \cdot S^{0.15} \cdot t^{0.15}} \mathrm{~m} / \mathrm{min}$ if $S \leq 0.2 \mathrm{~mm} / \mathrm{rev}$

$V=\frac{C_{v}}{T^{0.35} \cdot S^{0.45} \cdot t^{0.15}} \mathrm{~m} / \mathrm{min}$ if $S>0.2 \mathrm{~mm} / \mathrm{rev}$

- turning with up to $0.06 \mathrm{~mm} / \mathrm{rev}$ supplies using cutters where blades are made of BK6OM alloys:

$V=\frac{C_{v}}{T^{0.4} \cdot S^{0.2} \cdot t^{0.12}} \mathrm{~m} / \mathrm{min}$

$P z=C p \cdot V^{-0.12} \cdot S^{0.55} \cdot t^{0.8}$;

- turning with more than $0.07 \mathrm{~mm} / \mathrm{rev}$ supplies using cutters where blades are made of BK6M and BK8 alloys:

$V=\frac{C_{v}}{T^{0.25} \cdot S^{0.15} \cdot t^{0.15}} \mathrm{~m} / \mathrm{min}$ if $S \leq 0.2 \mathrm{~mm} / \mathrm{rev}$

$V=\frac{C_{v}}{T^{0.25} \cdot S^{0.45} \cdot t^{0.15}} \mathrm{~m} / \mathrm{min}$ if $S>0.2 \mathrm{~mm} / \mathrm{rev}$,

where:

$T$ - cutting power;

$C v$ - reference coefficients.

Taking into consideration dynamic deformations of the processed blank parts, the processing errors, resulting from the manufacturing system deformation, are determined using formulas [14]:

- if the blank parts are the centre fixed ones:

$\Delta=P_{i z g} \cdot\left[\frac{l^{3} \cdot \mu}{48 \cdot E \cdot I}+\frac{1}{j_{s}}+\frac{1}{4} \cdot\left(\frac{1}{j_{p}}+\frac{1}{j_{z}}\right)\right]$;

- if the blank part is fixed in a holder and in the dead centre:

$\Delta=P_{i z g} \cdot\left[\frac{l^{3} \cdot \mu}{102 \cdot E \cdot I}+\frac{1}{j_{s}}+\frac{1}{4} \cdot\left(\frac{1}{j_{p}}+\frac{1}{j_{z}}\right)\right]$.

Travelling rests and steady rests are applied to truss long nonrigid parts (i.e. bodies of revolution). Turning with a steady rest should take into consideration stiffness of all the three supports (a rest is concerned as a pin bearing). 
If turning takes place in the centres and a rest is located in the middle of a part, then the maximum deflection will be observed in terms of the load action between the supports [14]:

$$
f_{\max }=0.015 \frac{P_{i z g} \cdot l^{3}}{E \cdot I} \text {. }
$$

Dynamic deflection is:

$$
f_{\text {din }} \cdot \mu \cdot f_{m}=\frac{\mu \cdot 0.015 \cdot P_{i z g} \cdot l^{3}}{E \cdot I} \leq f_{d o p} .
$$

Cutting force $P z_{\text {dop }}$, corresponding to $f_{d o p}$, is:

$$
P z_{\text {dop }}=\frac{k \cdot E \cdot d \cdot f_{d o p}}{c^{3} \cdot \mu} \text {. }
$$

According to the data by [14]: $k=2.9$ if $P y=0.5 \cdot P z$ (for sharp cutters); and $k=1.4$ if $P y=P z$ (for blunt cutters).

Relying upon the analytical models, analyze tolerable cutting force taking into consideration the manufacturing system stiffness [14]:

$$
P z_{d o p}=\frac{k \cdot E \cdot d \cdot f_{d o p}}{c^{3} \mu+\left[\frac{1}{j_{s}}+\frac{1}{4}\left(\frac{1}{j_{p}+0.5 j_{l}}+\frac{1}{j_{z}+0.5 j_{l}}\right) \cdot k_{1} \cdot E \cdot I\right]},
$$

where:

$j_{l}-$ stiffness of a rest;

$k$ - values for formula (25);

$k_{1}=3.25$ if $P y=0.5 \cdot P z$ (for sharp cutters);

$k_{1}=2$ if $P y=P z$ (for blunt cutters).

Identify the maximum deflection while turning a part fixed in a holder, travelling rest, and dead centre $f_{\text {max }}=0.014 \frac{P_{i z g} \cdot l^{3}}{E \cdot I}$, and tolerable cutting force $P z_{\text {dop }}=\frac{k \cdot E \cdot d}{c^{3} \cdot \mu} \cdot\left(f_{d o p}-f_{c}\right)$

where:

$k=3.5, k_{1}=3.5$ if $P y=0.5 \cdot P z$ (for sharp cutters);

$k=2.4, k_{1}=3.4$ if $P y=P z$ (for blunt cutters).

The modeling results make it possible to evaluate cutability from the viewpoint of tolerable cutting force in terms of the specified processing error, manufacturing system stiffness, and nature of a part fixation on a lathe relying upon the $\nabla \leq \nabla_{z}$ ratio conditions (where $\nabla_{z}$-specified processing error) and $f \leq f_{\text {dop }}$ (where $f_{\text {dop }}$ - tolerable deflection of a part).

Processing accuracy modeling should involve comparison analysis of the relation between the cutability phenomena and the experimental results. Moreover, it is necessary to identify the cutability accuracy margin as well as the cutter power using the proposed formulas:

- cutability accuracy margin:

$$
\begin{aligned}
K^{R a} & =\frac{V_{k r}}{V_{R a}} ; \\
& - \text { cutter power: } \\
K^{T} & =\frac{V_{R a}}{V_{T}},
\end{aligned}
$$

where:

$V_{T}$ - cutting velocity corresponding to the specified efficiency life;

$V_{R a}$-cutting velocity corresponding to the maximum quality index of the processed surface;

$V_{k r}$ - critical cutting velocity corresponding to the specified processing error $\nabla_{z}$ and a part deflection $f_{z}$, taking into consideration manufacturing system stiffness and fixation conditions.

To formulate decisions, concerning the improvement of competitiveness of ore-mining machinery manufacturing, identify variation ranges of optimum velocities $V_{\text {opt }}$ inclusive of the required processing quality and the specified accuracy $V_{k r} \leq V_{o p t} \leq V_{R a} \leq V_{T} ; S_{\text {opt }} \leq S_{k r} ; t_{\text {opt }} \leq t_{k r}$.

Taking into consideration the proposed coefficients of accuracy margin and cutter efficiency, formulate optimality conditions: $K^{T} \rightarrow 1, K^{R a} \rightarrow 1$.

In light of requirements for theperformance reliability of ore-mining facilities, optimality conditions should be added:

$K^{R a}<K_{E t \sqsubset}^{R a} \cdots K^{T}>K_{E t}^{T}$,

where:

$K_{E t \sqsubset}^{R a}$ and $K_{E t \sqsubset}^{T}-$ coefficients of cutability margin and cutter efficiency corresponding requirements to performance reliability of ore-mining machinery.

Methods to identify cutability accuracy margin and cutter power have been developed. The methods have been taken as the basis for technology regulations to determine optimum conditions of the manufacturing system functioning and optimize cutting modes at the stage of the final machining of ore-mining machinery parts.

Since supply influence on the wear intensity as well as on the cutability accuracy is fundamental, it is required to carry out the research concerning supply influence on the dimensional wear of a tool and define area of tolerable supply values.

Flank wear results in a cutter tip distancing from the rotational axis of the processed blank part by the amount of radial wear. Hence, in the process of a cutter blunting and wearing, a variable systematic processing error (i.e. turning radius increase) arises.

In accordance with the general regularities of wear [13], [16], it is the most intensive in the initial period of a tool operation. Initial wear $U_{n}$ and its period $L_{n}\left(L_{n}\right.$ is considered as a period of a tool running-up) depends upon the materials of a cutting tool and a blank part being processed; quality and geometry of the cutting tool; and cutting modes. In terms of data by [13], initial wear length, expressed by cutting path length $L_{n}$, is $500-2000 \mathrm{~m}$. To model, assume $L_{n}=1000 \mathrm{~m}$.

Period two of a cutting tool life is characterized by ordinary wear being directly proportional to the cutting path. It is usual to evaluate the wear period by means of relative wear $U_{o}(\mu \mathrm{m} / \mathrm{km})$ using the formula [14]:

$U_{o}=\frac{U}{L}$

where:

$U$-dimensional wear in micrometers within cutting path $L$;

$L-$ cutting path within the ordinary wear area in kilometers.

Calculate the cutting tool wear, influencing the processing accuracy in terms of ordinary wear taking place within the ordinary wear area using the formula [13]: 
$U=\frac{U_{o} \cdot L}{1000}$

Cutting path length while turning is

$L=\frac{3.14 \cdot D \cdot l}{1000 \cdot S}$

where:

$D$ - diameter of a blank part being processed, $\mathrm{mm}$;

$l-$ length of a blank part being processed, $\mathrm{mm}$;

$S$ - supply, $\mathrm{mm} / \mathrm{rev}$.

Consider the initial wear of a cutting tool by means of increase in computational length $L$ of cutting path by some value $L_{d o p}$. Data of relative cutter wear $U_{o}[13]$ have been taken as the basis to calculate processing errors connected with dimensional wear of tools. According to [13], [16], cutting tool wear is calculated according to the formula:

$U=\frac{U_{o} \cdot\left(L+L_{d o p}\right)}{1000}$

Figure 5 represents the modeling results - dependences of cutting supply influence on a part $K$ conicity connected with the cutter $U$ wear while lathe machining. Analysis of the research results has shown that increase in the manufacturing system stiffness (i.e. in terms of vibration reduction) wear of a cutting tool decreases. In such cases, supply increase results in the increased dimensional tool durability. It improves processing accuracy under the conditions of sufficient stiffness of a manufacturing system as it is understood through the change in the part conicity.

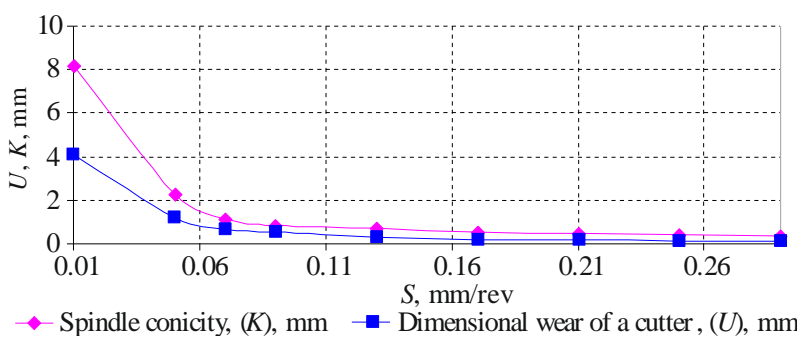

Figure 5. Cutting supply influence on a part conicity connected with dimensional wear of a cutting tool

The formed modeler makes it possible to predict machining accuracy connected with a cutting tool wear. During the modeling, area of tolerable cutting supplies is determined depending upon the specified accuracy criterion. In particular, it is done according to the part conicity while lathe turning.

The experiments with parts, made of 38XH3MFA steel, have helped identify that quality of the processed surface varies during the final machining along with the cutting tool blunting. Sometimes, it cannot meet the specified requirements. Changes in the processed surface geometry as well as its quality deterioration due to the cutting tool wear occur before the tool achieves a stage of extremely gross wear.

Use of technological criterion is known during final machining types [16] when the tool is considered as a worn one (blunt). As a result, the surface under processing cannot comply with the specifications any more. As it is known [13], [16], cutter power, corresponding to the definite wear value in the radial direction, is dimensional stability.
In the machining process of nonrigid spindle type, increase in the cutting tool wear results in the processed part dimension increase. In practice, dependence of a real size of the machines surface upon a cutter value is quite complicated. However, it has been determined with a certain error degree [13] that in terms of radial wear by $a$ value, diameter of the surface, being processed, will be equal to $d+2 a$ value.

To calculate the wear value, use [16] formula:

$a=h_{z} \cdot \operatorname{tg}(\lambda)$,

where:

$h_{z}$ - flank wear, mm;

$\lambda$ - clearance angle.

Figure 6 represents dependences of the cutter wear in a radial direction upon blunting on a clearance face. Analysis of the obtained results helps make a conclusion about the dimensional cutting-tool life according to a radial wear index, and identify a value of a tool blunting criterion taking into consideration tolerable errors of a dimension of the part being processed.

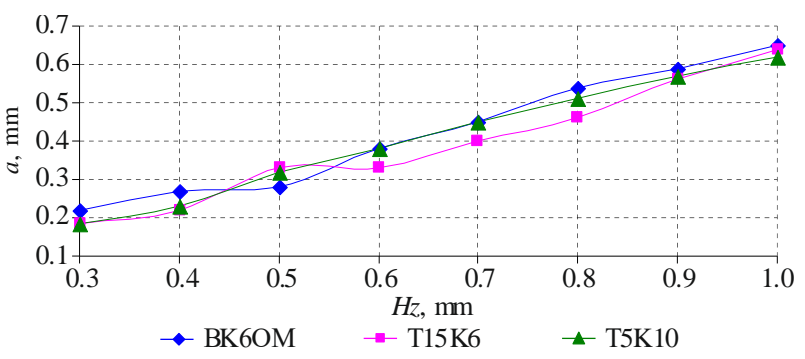

Figure 6. Dependence of radial wear upon flank wear

The research helps calculate tool life to select optimum grade of instrumental material for the specific tool-part pair. Determine total tool life as a product of sharpening number allowable by a plate in terms of the wear by an operate time (durability) during which the wear originated [17]:

$M=K \cdot T$,

where:

$K$ - sharpening number allowable by a plate in terms of the wear;

$T$-machine operate time (durability) of the tool corresponding to the specified wear degree.

Sharpening number, allowable by the plate width in terms of its flank wear, is determined using the formula [17]:

$$
K=\frac{\frac{2}{3} \cdot B}{\frac{h_{z} \cdot \operatorname{tg}(\lambda)}{\cos (\gamma)}+\Delta},
$$

where:

$h_{z}$ - flank wear;

$\lambda$ - clearance angle;

$\gamma$ - face angle;

$\Delta$-allowance for sharpening (being assumed as 0.1-0.2 mm).

Figure 7 shows dependences of the total life of BK6OM, T5K10, T15K6 cutters upon the value of tolerable flank wear. The plate width is $B=23 \mathrm{~mm}$. Calculate the total life of cutting tools depending upon the specified error and taking into consideration radial wear. 


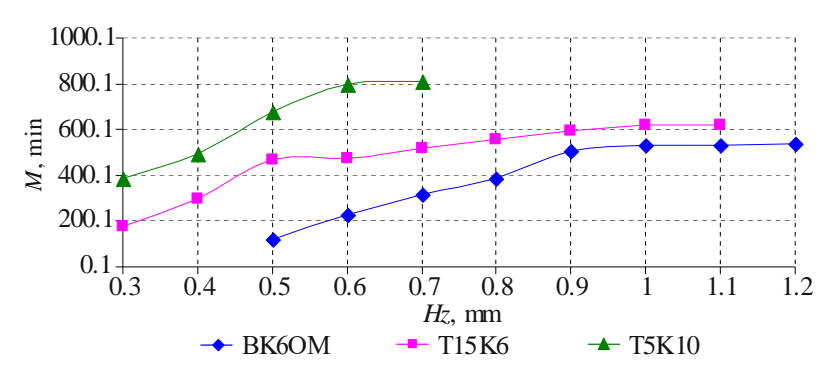

Figure 7. Dependence of the total cutter life upon flank wear

Analyze path length from flank wear using (29) and (30) formulas. The transformation results in the dependence:

$$
L=\frac{h_{z} \cdot \operatorname{tg}(\lambda) \cdot 1000}{U_{o}}-L_{d o p} \text {. }
$$

Figure 8 explains the modeling results - analysis of a cutting path length within the ordinary wear area upon flank wear.

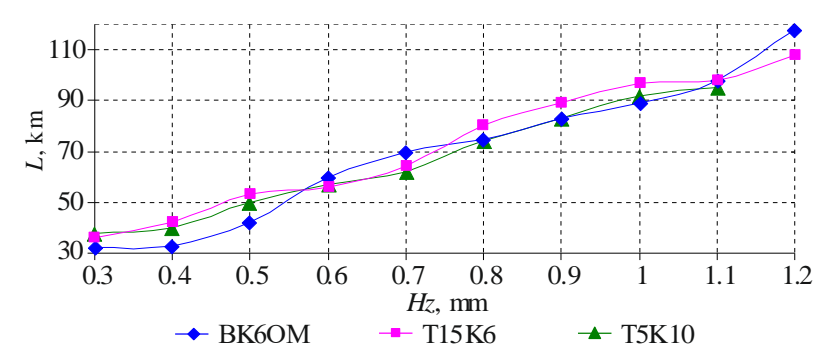

Figure 8. Dependences of a cutting path length upon the wear of cutting tools

Optimum cutting modes on the basis of the developed optimization model are selected taking into consideration machining under production conditions and comparing with modeling-based theoretical studies. The optimization involves minimum intensity of the tool wear in terms of the maximum surface quality inclusive of the specified machining accuracy; conditions of a part blank fixing on a lathe; and stiffness of a manufacturing system.

The developed mathematical models make it possible to analyze machining features with no additional industrial experiments. In this context, an opportunity is given to select a criterion value of the cutter blunting based upon dimensional cutter wear, and its influence on the dimensional accuracy of the processed parts under the specific industrial conditions. Tool life calculations help select the most optimal grade for a cutting plate taking into consideration the selected flank wear. Analysis of the data together with the results of roughness indices of the machined surface makes it possible to select the most preferable tool to obtain the required quality indices as well as cutting accuracy including cutability phenomena. Machining accuracy modeling helps determine critical cutting force as well as the machining modes which excess is limited by the specified dimensional accuracy of parts under processing in accordance with the production requirements.

The research, carried out in terms of the developed methods as a part of theoretical optimization model, has helped identify optimum functioning conditions of a manufacturing system. In the process of manufacturing order execution, optimum combination of tool - part pair has been proposed as well as machining modes for the specific industrial condi- tions, i.e. for the stages of rough and final machining taking into consideration structural conditions of metal of the processed part blanks and methods to obtain them.

In terms of the evaluation of economic efficiency of the made decisions, reduction in prime cost of processing of oremining machinery parts has been achieved. Among other things, the reduction is $13-15 \%$ to manufacture parts of the spindle types using lathes. Provision of the required competitiveness level in the context of the key indices of quality and machining accuracy of parts favoured the increase in reliability service of the equipment under the conditions of oremining production.

Results of the theoretical studies and research have been represented in engineering recommendations proposed to provide competitiveness of the ore-mining machinery manufacturing.

\section{Conclusions}

In the process of the industrial experiments, cutability features of ore-mining machinery parts, being processed, have been studied. The parts are made of steels with high physical and mechanical characteristics. The analysis of machining processes has helped identify relationship of cutting tool wear influence on the machining accuracy and quality depending upon the manufacturing system stiffness; and form the foundation to model technological processes and to develop a system of mathematical models.

The modeling of operating procedures has helped determine tolerable ranges of changes in cutting modes taking into consideration the specified accuracy and stiffness indices of manufacturing system. The abovementioned has made it possible to identify the reserves of production competitiveness and develop engineering recommendations for the improved reliability service of ore-mining facilities.

As a result of the developed analytical platform implementation, system solutions have been formulated to provide competitiveness of ore-mining machinery manufacturing under the conditions of large machine-building enterprise.

\section{Acknowledgements}

The research has been carried out on the basis of NKMZ CJSC on the assumption of scientific support by Research Institute of Specific Techniques. Financial support was provided while executing series of industrial orders to manufacture parts with high physical and mechanical characteristics. The authors express thanks to Oleksandr Yevdokymovych Provolotskyi, Professor, Doctor of Engineering, Director of the Research Institute of Specific Techniques, and authorities of NKMZ CJSC for their support while carrying out the research in workshops and laboratories of the enterprise.

\section{References}

[1] Derzhavna sluzhba statystyky Ukrainy. (2020). Retrieved from http://www.ukrstat.gov.ua/

[2] Prognoz mirovoy dinamiki potrebleniya uglya. (2019). Available at https://dtek.com/content/files/victor-levit.pdf

[3] Utverzhdena Energostrategiya Ukrainy do 2035 goda. (2017). Retrieved from https://jurliga.ligazakon.net/news/163494_utverzhdenaenergostrategiya-ukrainy-do-2035-goda

[4] Karaguzel, U., Olgun, U., Uysal, E., Budak, E., \& Bakkal, M. (2014). Increasing tool life in machining of difficult-to-cut materials using nonconventional turning processes. The International Journal of Advanced Manufacturing Technology, 77(9-12), 1993-2004. https://doi.org/10.1007/s00170-014-6588-7 
[5] Parida, A.K., Rao, P.V., \& Ghosh, S. (2019). Numerical analysis and experimental investigation in the machining of AISI 316 steel. Sädhanā, 45(1). https://doi.org/10.1007/s12046-019-1235-5

[6] El-Hossainy, T.M., El-Zoghby, A.A., Badr, M.A., Maalawi, K.Y., \& Nasr, M.F. (2010). Cutting parameter optimization when machining different materials. Materials and Manufacturing Processes, 25(10), 1101-1114. https://doi.org/10.1080/10426914.2010.480998

[7] Postnov, V.V., Khadiullin, S.Kh., Malakhov, E.N., \& Starovoytov, S.V. (2012). Issledovanie pokazateley, opredelyayushchikh rezhushchie svoystva instrumental'nykh tverdykh splavov pri obrabotke trudnoobrabatyvaemykh materialov. Vestnik UGATU, 16(8(53)), 118-125.

[8] Philip Selvaraj, D., Chandramohan, P., \& Mohanraj, M. (2014). Optimization of surface roughness, cutting force and tool wear of nitrogen alloyed duplex stainless steel in a dry turning process using Taguchi method. Measurement, (49), 205-215. https://doi.org/10.1016/..measurement.2013.11.037

[9] Heisel, U., Kryvoruchko, D.V., Zaloha, V.A., Storchak, M., Emelyanenko, S.S., \& Selivonenko, S.N. (2008). Finite element analysis of cutting force dynamics. Proceedings of the $11^{\text {th }}$ CIRP International Workshop on Modeling of Machining Operations, 163-170.
[10] Heisel, U., Kryvoruchko, D.V., Zaloha, V.A., \& Storchak, M. (2007). Cause analysis of errors in Fe prediction orthogonal cutting performances. Proceedings of the $10^{\text {th }}$ CIRP International Workshop on Modeling of Machining Operations, 141-148.

[11] Dessoly, V., Melkote, S.N., \& Lescalier, C. (2004). Modeling an verification of cutting tool temperatures in rotary tool turning of hardened steel. International Journal of Machine Tools and Manufacture, 44(14), 1463-1470. https://doi.org/10.1016/j.ijmachtools.2004.05.007

[12] Ayupov, V.V. (2017). Matematicheskoe modelirovanie tekhnicheskikh system. Perm', Rossiya: IPTs Prokrost'.

[13] Matalin, A.A. (1985). Tekhnologiya mashinostroeniya. Leningrad, Rossiya: Mashinostroenie.

[14] Kolev, K.S., \& Gorchakov, L.M. (1976). Tochnost' obrabotki i rezhimy rezaniya. Moskva, Rossiya: Mashinostroenie.

[15] Rezhimy rezaniya trudnoobrabatyvaemykh materialov. (1976). Moskva, Rossiya: Mashinostroenie.

[16] Vul'f, A.M. (1973). Rezanie metallov. Leningrad, Rossiya: Mashinostroenie.

[17] Arshinov, V.A., \& Alekseev, G.A. (1967). Rezanie metallov i rezhushchiy instrument. Moskva, Rossiya: Mashinostroenie.

\section{Аналітична платформа забезпечення конкурентоспроможності виробництва гірничорудних машин}

\section{О. Паршина, Ю. Паршин}

Мета. Розробка аналітичної платформи для забезпечення конкурентоспроможності виробництва гірничорудних машин.

Методика. Аналітична платформа об'єднує п'ять модулів. Платформою передбачено визначення області оптимальних режимів обробки для кожної пари “інструмент - деталь”. Дослідження оброблюваності різанням проведені у виробничих умовах 3АТ НКМЗ на деталях типу валів зі сталі 38ХНЗМФА. Для проведення експериментів були підготовлені різці з різних інструментальних матеріалів, заточені алмазним кругом із забезпеченням певних геометричних параметрів. Деталі оброблялися на токарно-гвинторізний верстаті 1А680 без охолодження. Як критерій затуплення різців прийнятий знос по задній поверхні.

Результати. Виявлено взаємозв'язки технологічних процесів обробки деталей гірничорудних машин, зокрема встановлені закономірності зносу ріжучих інструментів з урахуванням впливу на точність та якість оброблюваних поверхонь залежно від жорсткості технологічної системи і умов закріплення деталей в процесі механічної обробки. Розроблено методику визначення показника запасу точності технологічної системи, що дозволяє виявити резерви підвищення конкурентоспроможності виробництва гірничорудних машин з урахуванням заданих обмежень за точністю та якістю обробки. Розроблено математичні моделі, практичне використання яких дозволяє визначити області оптимальних режимів механічної обробки деталей гірничорудних машин, уявити порівняльну характеристику технологічних процесів з урахуванням показників точності обробки й впливу зносу на розмірну стійкість різального інструмента.

Наукова новизна. Науково обгрунтовано, що область оптимальних режимів визначається за системною сукупністю запропонованих критеріїв з урахуванням заданих показників якості, точності та продуктивності технологічних процесів обробки деталей гірничорудних машин.

Практична значимість. Виявлені закономірності становлять аналітичну основу прийняття рішень щодо забезпечення конкурентоспроможності виробництва за рахунок оптимізації технологічних процесів, підвищення точності, якості обробки та експлуатаційної надійності деталей гірничорудних машин.

Ключові слова: моделювання процесу різання, деталі гірничорудних машин, показники якості, точність обробки

\section{Аналитическая платформа обеспечения конкурентоспособности производства горнорудных машин}

\section{Е. Паршина, Ю. Паршин}

Цель. Разработка аналитической платформы для обеспечения конкурентоспособности производства горнорудных машин.

Методика. Аналитическая платформа объединяет пять модулей. Платформой предусмотрено определение области оптимальных режимов обработки для каждой пары “инструмент - деталь". Исследования обрабатываемости резанием проведены в производственных условиях ЗАО НКМЗ на деталях типа валов из стали 38ХНЗМФА. Для проведения экспериментов были подготовлены резцы из различных инструментальных материалов, заточены алмазным кругом с обеспечением определенных геометрических параметров. Детали обрабатывались на токарно-винторезном станке $1 \mathrm{~A} 680$ без охлаждения. В качестве критерия затупления резцов принят износ по задней поверхности.

Результаты. Выявлены взаимосвязи технологических процессов обработки деталей горнорудных машин, в частности установлены закономерности износа режущих инструментов с учетом влияния на точность и качество обрабатываемых поверхностей в зависимости от жесткости технологической системы и условий закрепления деталей в процессе механической обработки. Разработана методика определения показателя запаса точности технологической системы, что позволяет выявить резервы повышения конкурентоспособности производства горнорудных машин с учетом заданных ограничений по точности и качеству обработки. Разработаны математические модели, практическое использование которых позволяет определить области оптимальных режимов механообработки деталей горнорудных машин, представить сравнительную характеристику технологических процессов с учетом показателей точности обработки и влияния износа на размерную стойкость режущего инструмента.

Научная новизна. Научно обосновано, что область оптимальных режимов определяется по системной совокупности предложенных критериев с учетом заданных показателей качества, точности и производительности технологических процессов обработки деталей горнорудных машин.

Практическая значимость. Выявленные закономерности составляют аналитическую основу принятия решений по обеспечению конкурентоспособности производства за счет оптимизации технологических процессов, повышения точности, качества обработки и эксплуатационной надежности деталей горнорудных машин.

Ключевые слова: моделирование прочесса резания, детали горнорудных машин, показатели качества, точность обработки

\section{Article info}

Received: 15 February 2020

Accepted: 28 July 2020

Available online: 4 September 2020 